\title{
Zprávy ze XVII. výročního sjezdu České kardiologické společnosti, Brno, 10.-13. května 2009
}

\section{Výroční sjezd pohledem hlavního organizátora}

XVII. výroční sjezd je již historií a pevně věřím, že splnil veškerá očekávání. Snad bylo jen minimum účastníků, kteří odjižděli zklamáni. Sjezdu se zúčastnilo několik významných hostů. Kromě účastníků z České republiky je potěšitelná i velká účast kardiologů ze Slovenska.

Z pohledu zajištění odborného programu musím říci, že jeho př́prava probíhala naprosto bezchybně. Pracovní skupiny odvedly svou práci na jedničku. Zorganizovaly velmi zajímavé bloky, došlo také velké množství volných sdělení, která jsme se snažili spravedlivě rozdělit na ústní a posterovou prezentaci. Je třeba říci, že zájem lékařu o aktivní účast na kongresu narůstá. Podle mého soudu je to hlavně tím, že zejména pro mladé lékaře se vystoupení na národním kardiologickém kongresu stává stále více prestižní záležitostí.

$\mathrm{Z}$ organizačního pohledu lze konstatovat, že $\mathrm{k}$ mnoha změnám na kongresu nedošlo. Asi je to tím, že předchozí sjezdy byly velmi úspěšné, tak jsme se snažili pro účastníky připravit podobný model, $\mathrm{s}$ jakým byli $\mathrm{v}$ minulosti spokojeni. Také $\mathrm{v}$ tomto roce jsme při prŕpravě dbali na to, aby kongres měl vysokou odbornou úroveň, ale zároveň i postgraduální charakter, a aby program v maximální míře oslovil vedle samotných kardiologů také internisty a praktické lékaře. Vysoká odborná úroveň byla dána do velké míry už samotnými přednášejícími, kterými byli ve velké většině renomovaní čeští kardiologové.

Ve čtyřech sálech probíhaly paralelně vyzvané přednášky, jejichž řečníky vybírali zástupci dané pracovní skupiny. Velmi cenná byla i vystoupení zahraničních hostů. Jmenujme především profesora Roberta Ferrariho (prezidenta elect Evropské kardiologické společnosti), který na začátku slavnostního zahájení vyzval české kardiology $\mathrm{k}$ větší účasti na evropských kongresech. Jedním z významných hostů kongresu byl profesor Bernard Gersh z Mayo Clinic, který se věnoval problematice léčby chronické anginy pectoris u diabetiků.

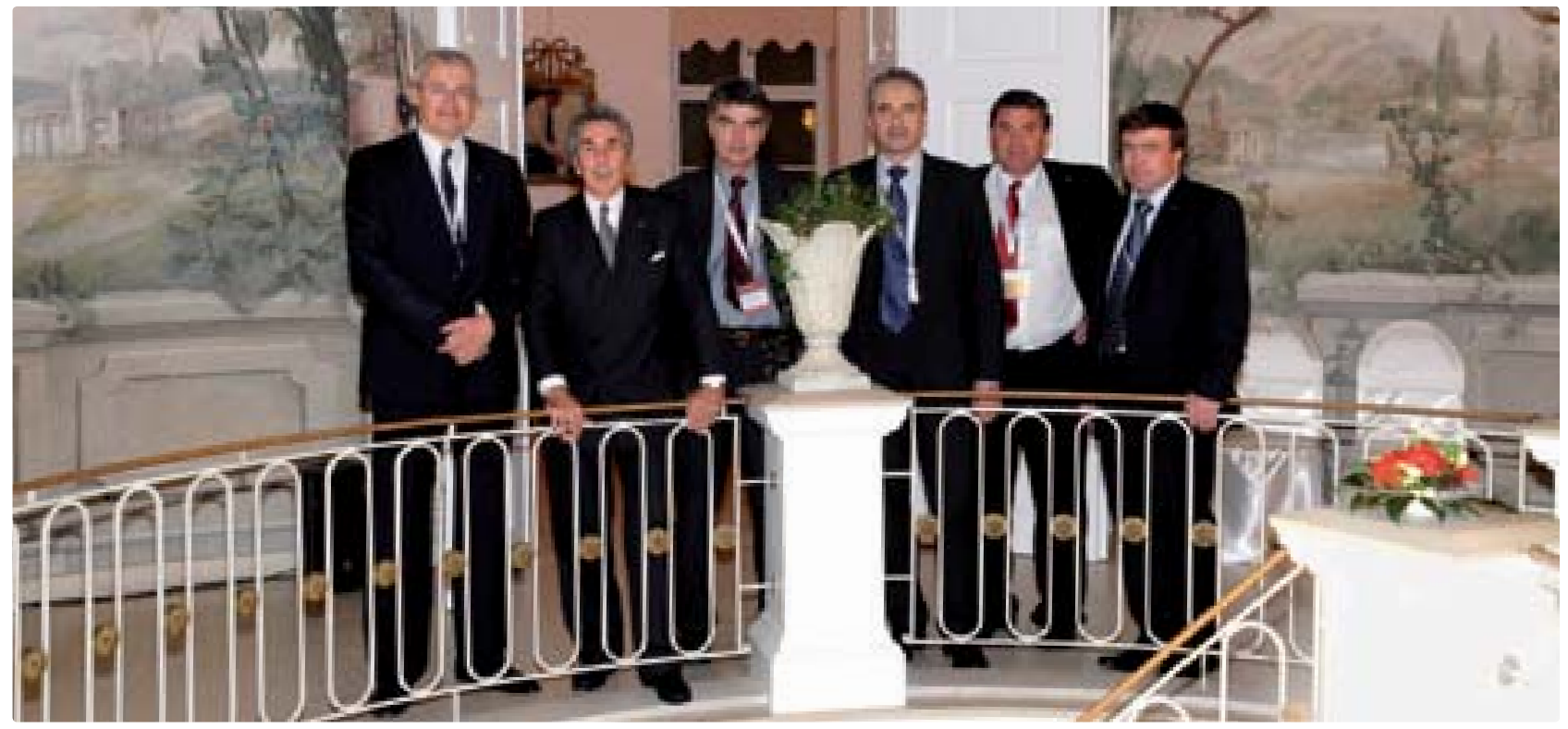

Prof. Petr Widimský, prof. Robert Ferrari (prezident Evropské kardiologické společnosti), doc. Václav Chaloupka, prof. Josef Kautzner, prof. Jindřich Špinar, prof. Aleš Linhart 
Největší novinkou bylo představení Českého kardiovaskulárního vzdělávacího institutu, který si klade za cíl koordinovat a po odborné stránce zajištovat systém postgraduálních kursů a školení pro lékaře před atestací $\mathrm{z}$ kardiologie. Představitelé České kardiologické společnosti se rozhodli, že na rozpad systému postgraduálního vzdělávání, kterého jsme v poslední době byli svědky, je třeba nějakým způsobem reagovat. Proto se po vzoru nizozemských kolegů rozhodli iniciovat založení tohoto institutu. V rámci jeho představení byly v úvodním dnu kongresu připraveny dva přednáškové bloky, věnované specializační př́ipravě $\mathrm{k}$ atestaci. $\mathrm{V}$ prvním $\mathrm{z}$ nich - „Abecedě mladého kardiologa" byla přehledným způsobem zpracována čtyři vybraná témata. Ve druhém bloku, který byl nazván „Výuka pomocí kasuistik“, byla naopak na typické kasuistice demonstrována správná diferenciálně-diagnostická úvaha, adekvátní sled vyšetřovacích metod a léčebných postupů, jež odpovídají daným příznakům. Po skončení těchto přednášek dostal každý účastník certifikát dokládající jejich absolvování. Chtěli bychom uspořádat podobné semináře alespoň dvakrát do roka, pokud možno na více místech České republiky. Nejbližší další kurs, který připravili kolegové z FN Motol, by měl být například věnován problematice kardiomyopatií. Účastníci by se $\mathrm{v}$ něm měli prakticky seznámit $\mathrm{s}$ různými diagnostickými postupy. V programu kongresu naopak vypadl obvyklý blok přednášek zahraničních účastníků, kteří svá sdělení letos prezentovali v blocích jednotlivých pracovních skupin.

Doprovodná výstava byla pěkná, spíše však skromnější než $v$ loňských letech. Je to dáno částečnou stagnací farmaceutických firem a také prrísným zákonem o reklamě. $\mathrm{V}$ posledních letech zažíváme obrovský rozmach různých nemedikamentózních terapeutických postupů, at' už jde o intervenční kardiologii s novými generacemi stentů nebo nejrůznějšími implantabilními kardiovertery-defibrilátory či biventrikulárními stimulátory. Problém je zřejmě v tom, že za posledních deset let se ve farmakoterapii v kardiologii neobjevil žádný nový převratný lék, který by výrazně změnil náš pohled na léčbu kardiovaskulárních onemocnění. Jde spíše o potvrzování toho, co známe. Nově prováděné studie nás hlavně utvrzují v tom, co jsme už znali na konci dvacátého století; hledáme $\mathrm{k}$ tomu částečně nové indikace pro existující přípravky.

Tradičně úspěšné byly i hlavní doprovodné akce, především Kardioběh Jiř́iho Tomana, kterého se letos zúčastnilo přes 100 běžců, ale i slavnostní zahájení a závěrečný galavečer.

Těšíme se na Vás v roce 2010 a přivítáme veškeré náměty na zlepšení.

Prof. MUDr. Jindřich Špinar, CSc.,

Interní kardiologická klinika, FN Brno-Bohunice a LF MU, Brno

\section{Pracovní skupina Kardiovaskulární farmakoterapie}

Tradičními programovými bloky pracovní skupiny Kardiovaskulární farmakoterapie na výročním sjezdu ČKS jsou informace o výsledcích zajímavých nebo důležitých nedávno ukončených klinických studií a informace o kardiovaskulárních lécích, které byly v posledním roce $\mathrm{v}$ České republice nově registrovány. Letos došlo $\mathrm{z}$ praktických důvodů $\mathrm{k}$ několika formálním změnám.

Roky jsme byli zvyklí, že klinické studie jsou obvykle prováděny s léky - bud' novými nebo $\mathrm{v}$ nových indikacích, bud ve srovnání s placebem nebo s jinou aktivní látkou, tzv. komparátorem. O výsledcích takových vybraných farmakologických klinických studií pracovní skupiny Kardiovaskulární farmakoterapie se tradičně na výročním sjezdu informuje $\mathrm{v}$ sekci HOTLINES. V posledních letech se ale objevuje čím dál více nefarmakologických klinických studií. Testují se v nich různé prístrojové léčebné postupy, např. ICD, CRT, různé antiarytmické ablační techniky, chirurgické či katetrizační revaskularizační strategie, ale také rehabilitační postupy, změny životního stylu apod. Tyto nefarmakologické klinické studie byly pochopitelně pracovní skupinou Kardiovaskulární farmakoterapie opomíjeny. Protože však výsledky těchto studií jsou neméně důležité jako výsledky studií farmakologických, bylo výborem ČKS rozhodnuto, že počínaje letošním rokem budou na výročním sjezdu bloky HOTLINES dva. První bude vždy připravován výborem ČKS ve spolupráci s ostatními pracovními skupinami a budou v něm prezentovány výsledky jednak původních českých studií (pokud takové v uplynulém roce byly) a jednak výsledky vybraných nefarmakologických studií. Původní české studie byly letos prezentovány dvě.

Výsledky první z nich - studie FACS (Fluvastatin in the therapy of Acute Coronary Syndrome) - přednesl její hlavní autor MUDr. Oštádal z Kardiologického oddělení Nemocnice $\mathrm{Na}$ Homolce. $\mathrm{V}$ několika centrech do ní bylo zařazeno 156 nemocných s akutními koronárními syndromy, kteří byli při přijetí na koronární jednotku randomizováni bud' k užívání 80 mg fluvastatinu denně, nebo placeba. Primárním sledovaným ukazatelem v této studii byly plazmatické koncentrace některých biomarkerů zánětu, konkrétně CRP, interleukinu 6 a PAPP-A, které nebyly podáváním fluvastatinu významně ovlivněny. Při časné léčbě fluvastatinem však poklesl o více než $50 \%$ výskyt velkých kardiovaskulárních př́ihod, které představovaly sekundární ukazatele studie. Výsledek je nepochybně velmi zajímavý, ale vzhledem $\mathrm{k}$ velikosti studie je nezbytné ho oveřit $\mathrm{v}$ daleko větší mortalitní/morbiditní studii.

Druhou prezentovanou původní českou studií byly Výsledky dlouhodobého sledování trendi̊ výskytu hlavních rizikových faktorů aterosklerózy $\mathrm{v}$ reprezentativním vzorku české populace hlavní autorkou tohoto dlouhodobého sledování prof. Cífkovou z Oddělení preventivní kardiologie IKEM. To, o jak záslužnou práci se jedná, asi není třeba zdůrazňovat. Existence dlouhodobých údajů o prevalenci jednotlivých hlavních rizikových

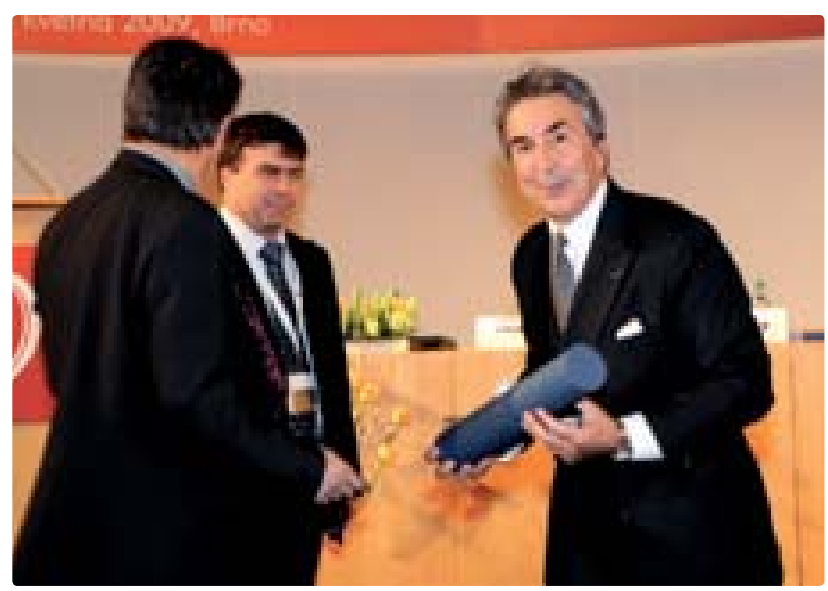

Prof. Rober Ferrari 


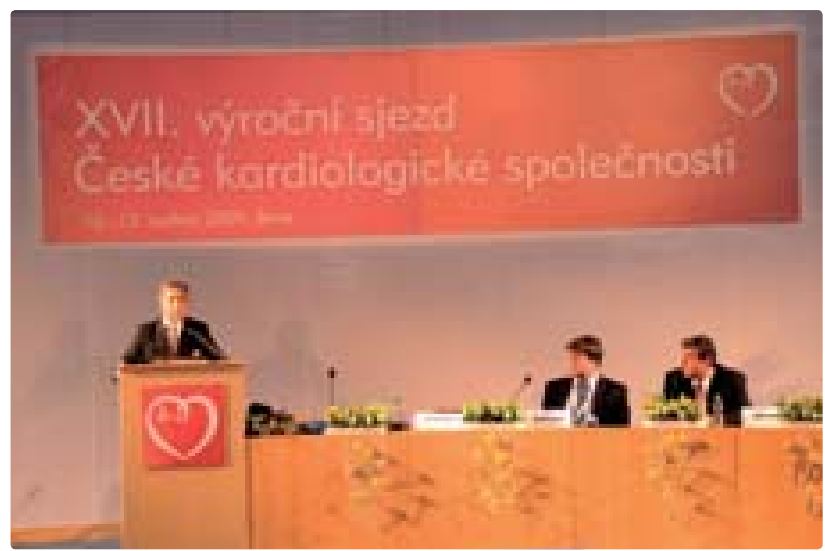

Účastníci sjezdu se zájmem sledovali přednášku prof. Roberta Ferrariho

faktorů v české populaci např. umožnila konstrukci tabulek systému SCORE pro stanovení absolutního kardiovaskulárního rizika, které jsou specifické pro českou populaci, a které jsou součástí společných českých guidelines pro kardiovaskulární prevenci v dospělém věku.

Nefarmakologické studie, jejichž výsledky byly představeny, byly čtyři. Výsledky studie TERMOCOOL AF prezentoval doc. Neužil z Kardiologického oddělení Nemocnice Na Homolce, které do této studie přispělo podstatnou částí nemocných. Šlo o prospektivní, randomizovanou studii, jejímž cílem bylo sledovat dlouhodobý výsledek katetrizační ablace pro paroxysmální fibrilaci síní ve srovnání s medikamentózní léčbou. Studie ukázala lepší výsledky katetrizační léčby, při které zůstávalo na konci sledování na sinusovém rytmu $64 \%$ nemocných ve srovnání s pouze $16 \%$ nemocných, které byli léčeni medikamentózně. Výsledky studie SYNTAX prezentoval MUDr. Kala z Interní kardiologické kliniky FN Brno.

V této studii byly porovnávány dlouhodobé výsledky katetrizační koronární revaskularizace (PCI) a implantací lékového stentu (DES) s výsledky chirurgické revaskularizace myokardu (CABG) u nemocných s nově zjištěným významným aterosklerotickým postižením koronárního řečiště, které technicky umožňovalo obě léčebné strategie. Studie byla uspořádána tak, aby prokázala srovnatelný účinek PCI s DES. K jedné nebo druhé léčebné strategii bylo randomizováno 1800 nemocných, kteří byli sledováni po dobu jednoho roku od výkonu. Za toto časové období nebyl mezi oběma skupinami významný rozdíl v celkové mortalitě, výskytu infarktů myokardu, okluzí intervenovaných tepen nebo implantovaných bypassů ani kombinovaného klinického výsledného ukazatele. Nemocní léčení CABG měli menší potřebu opakované koronární revaskularizace, ale měli naopak vyšší výskyt mozkových cévních příhod. A konečně poslední prezentovanou nefarmakologickou studií byla studie STICH (Surgical Treatment for Ischaemic Heart failure), o jejíž výsledcích referovala MUDr. Jandová z IKEM, Praha. Cílem této studie bylo zjistit, zda u nemocných se systolickou dysfunkcí levé komory, kteří jsou indikováni ke CABG, je přínosné provést navíc ještě rekonstrukční výkon na levé komoře. Randomizováno bylo 1000 nemocných s ejekční frakcí $\leq 0,35$. Nebyl pozorován ani krátkodobý (30 dnů), ani dlouhodobý (čtyři roky) klinický př́nos rekonstrukce levé komory. Rekonstrukční výkon byl spojen pouze s významně vyššími náklady na léčbu.

Do sekce HOTLINES pořádané pracovní skupinou Kardiovaskulární farmakoterapie bylo vybráno celkem šest farmakologických klinických studií. V posledních letech jsme si již začali zvykat na to, že farmakologické studie bud' nevycházejí vůbec, nebo vycházejí jinak, než se obecně očekávalo.
Studie JUPITER, jejíž výsledky byly poprvé prezentovány na kongresu AHA v listopadu 2008, je ale naprostou výjimkou. Studie zkoumala tzv. pleiotropní účinky statinů, konkrétně účinek 20 mg rosuvastatinu ve srovnání s placebem u 19000 osob s normální plazmatickou koncentrací LDL-cholesterolu $(<3,36 \mathrm{mmol} / \mathrm{l})$, které ale měly zvýšenou koncentraci C-reaktivního proteinu stanoveného vysoce senzitivní metodou (hs-CRP $\geq 2 \mathrm{mg} / \mathrm{l}$ ). Původně byla plánována průměrná doba sledování čtyři roky, ale studie byla předčasně ukončena již po průměrné době sledování 1,9 roku, protože rosuvastatin vedl k vysoce významnému poklesu výskytu primárního kombinovaného klinického výsledného ukazatele (KV mortalita + IM + CMP + nestabilní AP + koronární revaskularizace) o $44 \%$. Pokles výskytu jednotlivých složek primárního výsledného ukazatele byl rovnoměrný a pohyboval se kolem $50 \%$; dokonce i celková mortalita byla rosuvastatinem významně snížena o 20 \%. Rosuvastatin v denní dávce 20 mg vedl k průměrnému snížení plazmatických koncentrací LDL-cholesterolu o $50 \%$; polovina intervenovaných osob dosáhla koncentrace $<1,43 \mathrm{mmol} / \mathrm{l}$ a čtvrtina dokonce $<1,14 \mathrm{mmol} / \mathrm{l}$ ! Přesto bylo podávání rosuvastatinu velmi bezpečné, jediným nežádoucím účinkem byl mírně vyšší počet nově diagnostikovaných případů diabetes mellitus a v průměru o 0,1 \% vyšší koncentrace glykovaného hemoglobinu. Prezentovány byly i zcela nedávné výsledky jedné z mnoha podstudií studie JUPITER, které ukázaly, že rosuvastatin také vedl $\mathrm{k}$ významně nižšímu výskytu případů žilního tromboembolismu o $43 \%$. Oslnivé výsledky studie JUPITER a jejích podstudií již stačily rozpoutat rozsáhlou a kontroverzní diskusi o řadě otázek, např. o tom, zda rozšírit léčbu statiny do primární prevence, jak nízké by měly být cílové hodnoty, zda má cenu provádět screening hs-CRP a hlavně, kolik by to všechno stálo.

Studie AURORA je naopak př́kladem studie, která „nevyšla“. Byl v ní srovnáván také účinek rosuvastatinu, tentokráte v denní dávce $10 \mathrm{mg}$ ve srovnání s placebem u nemocných v terminálním stadiu renálního selhání, včetně hemodialyzovaných nemocných. Léčba rosuvastatinem byla i u těchto vysoce rizikových nemocných bezpečná, ale vůbec neovlivnila výskyt primárního kombinovaného ukazatele (KV mortalita + IM + CMP). Je to již druhá studie, která ukázala, že podávání statinů u nemocných s pokročilým renálním selháváním nemá smysl. Tou první byla studie $4 \mathrm{D}$, která přinesla podobné výsledky s atorvastatinem.

Studie ATHENA hodnotila účinky antiarytmika dronedaronu ve srovnání s placebem u nemocných s různými formami fibrilace síní. Dronedaron je derivátem amiodaronu, neobsahuje ale v molekule atom jodu, proto nemá nežádoucí účinky na funkci štítnice. Navíc je lipofilní, méně se kumuluje ve tkáních, má proto proti amiodaronu "normálnější (jeho biologický poločas je zhruba 24 hodin ve srovnání asi s 50 dny u amiodaronu) a menší tkáňovou toxicitu.

Ve starších klinických studiích EURIDIS a ADONIS vedl dronedaron ke snížení výskytu recidiv fibrilace síní a k prodloužení času do recidivy arytmie. Pak však byla předčasně ukončena studie ANDROMEDA u nemocných s významnou systolickou dysfunkcí levé komory pro zvýšenou mortalitu nemocných užívajících dronedaron. Zdálo se, že to bude znamenat konec dalšího vývoje tohoto antiarytmika. Studie ATHENA však dopadla dobře a její výsledky dávají dronedaronu novou šanci. Do této studie bylo zařazeno celkem 4628 nemocných s různými formami fibrilace síní (paroxysmální i chronickou), kteří byli randomizováni k užívání bud' dronedaronu v denní dávce $2 \times 400 \mathrm{mg}$, nebo placeba. Dronedaron snížil výskyt primárního kombinovaného klinického ukazatele (celková mortalita + KV hospitalizace) o $24 \%$, KV mortalitu o $29 \%$ a celkovou mortalitu o $16 \%$. 
Ve studii ACTIVE A se porovnávala účinnost duální protidestičkové léčby kombinací clopidogrelu a kyseliny acetylsalicylové (ASA) proti monoterapii ASA u nemocných s různými formami fibrilace síní, kteří nemohou být z jakéhokoli důvodu léčeni antikoagulací warfarinem. Ve studii bylo randomizováno celkem 7554 nemocných, z toho 426 v českých centrech. Primárním sledovaným kombinovaným klinickým ukazatelem byl součet CMP + IM + systémových embolizací (ne do CNS). Duální protidestičková léčba snížila výskyt primárního ukazatele o $11 \%$ proti monoterapii ASA; výskyt CMP dokonce o $28 \%$, výskyt IM o $22 \%$. Silnější účinek byl však zaplacen o 57 \% vyšším výskytem hemoragických komplikací.

Velmi zajímavé a praktické informace přinesla informace o výsledcích dvou nezávislých průzkumů kanadských zdravotních pojištoven, pro které se ujaly názvy ONTARIO I a II. V obou průzkumech byl sledován dlouhodobý osud nemocných, kteři užívali různé druhy inhibitorů ACE. V prvním, starším retrospektivním průzkumu byl sledován osud 7512 nemocných, kterým byl inhibitor ACE aplikován při hospitalizaci pro AIM nebo nejpozději od jednoho měsíce od IM v rámci farmakologické sekundární prevence. Průměrná doba sledování byla dva roky, minimální jeden rok. Ukázalo se, že nejlepší prognózu měli nemocní, kteří užívali ramipril a perindopril. Ti, kteří užívali ostatní v Kanadě používané inhibitory ACE (captopril, enalapril, quinapril, lisinopril a fosinopril), měli vyšší mortalitu. Ve druhém průzkumu, jehož výsledky byly publikovány nedávno, byl podobným způsobem sledován osud 43316 nemocných s chronickým srdečním selháním, kteř́ byli léčeni různými inhibitory ACE. Nejlepší prognózu měli opět nemocní, kteří užívali ramipril, perindopril a v této studii i cilazapril. Nemocní, kteří užívali ostatní výše uvedené inhibitory ACE, měli prognózu (vyjádřenou mortalitou) horší. $\mathrm{Z}$ výsledků těchto dvou průzkumů jasně vyplývá, že účinky inhibitorů ACE nejsou stejné a mezi jednotlivými inhibitory ACE jsou klinicky významné rozdíly. V kanadských průzkumech nebyly hodnoceny spirapril, trandolapril a moexopril, které se v Kanadě nepoužívají.

Poslední prezentací v bloku HOTLINES byly opět výsledky dvou studií, jedné poprvé prezentované v listopadu 2008 na výročním kongresu AHA v New Orleans, a druhé př̀edstavené v březnu 2009 na výročním sjezdu ACC v Orlandu. Obě tyto studie testovaly význam monitorování plazmatických koncentrací natriuretických peptidů pro řízení léčby chronického srdečního selhání.

V první z těchto studií - TIME CHF - bylo randomizováno 622 nemocných s chronickým srdečním selháním bud' k řízení léčby podle koncentrací BNP, nebo k řízení léčby podle klinického stavu, tedy podle symptomů. U nemocných, u kterých byla léčba řízena podle BNP, docházelo častěji k úpravám medikace,

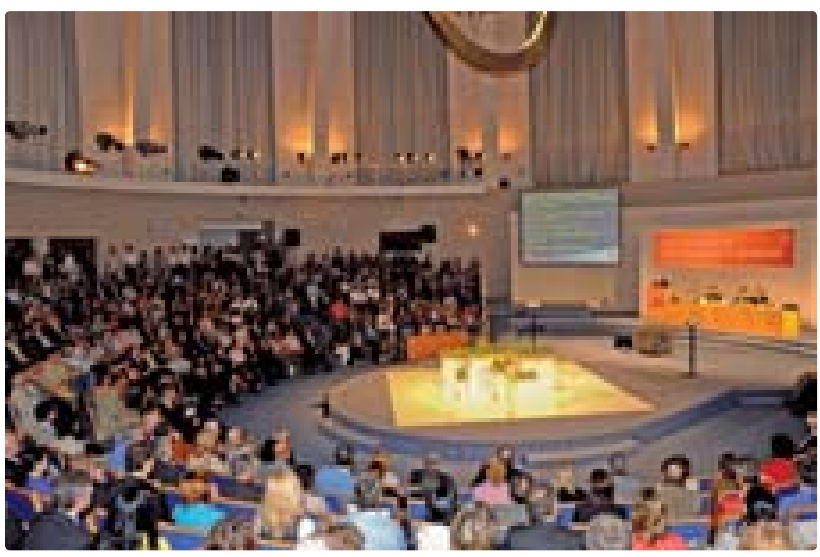

Z přednáškového sálu v Rotundě zejména zvyšováním dávek podávaných léků, a byl u nich také nižší výskyt kombinovaného klinického ukazatele (celková mortalita + hospitalizace ze všech důvodů) daný především poklesem mortality. Tyto rozdíly ve výsledcích léčby byly patrny zejména u nemocných mladších 75 let, u starších se rozdíly stíraly.

Druhá ze studií - PRIMA - měla podobné uspořádání. Bylo v ní randomizováno 345 nemocných s chronickým srdečním selháním k řízení léčby bud' podle koncentrací NT-proBNP, nebo podle klinického stavu. Podobně jako v předcházející studii vedla léčba řízená koncentracemi natriuretických peptidů $\mathrm{k}$ častějším úpravám léčby, zejména zvyšování dávek diuretik a inhibitorů $\mathrm{ACE}$, méně pak beta-blokátorů. Na rozdíl od předchozí studie ale nevedla ke statisticky nižšímu výskytu kombinovaného klinického ukazatele, opět složeného z celkové mortality a hospitalizací ze všech důvodů. Význam natriuretických peptidů pro optimalizaci léčby nemocných s chronickým srdečním selháním tak zůstává i nadále kontroverzní.

V další části HOTLINES představil prof. Bultas krátce čtyři nové kardiovaskulární léky, které byly v posledním roce v České republice registrovány. Vlastně všechny čtyři již byly registrovány centrální registrační procedurou současně v celé Evropské unii. Společné jim také je, že ani jeden z nich zatím nemá u nás stanovenou úhradu.

Jedná se o nový protidestičkový lék ze skupiny thienopyridinových blokátorů destičkových ADP receptorů prasugrel (Effient $^{\circledR}$, Eli Lilly a Daiichi Sankyo), jehož výhodami ve srovnání s clopidogrelem je nízký výskyt rezistence na léčbu, rychlejší nástup účinku, menší riziko lékových interakcí a o něco vyšší účinnost, která je ale vykoupena asi o třetinu vyšším rizikem krvácivých komplikací. Lék je registrován pro duální protidestičkovou léčbu ( $\mathrm{v}$ kombinaci s ASA) nemocných $\mathrm{s}$ akutním koronárním syndromem, u nichž se provádí PCI. Dalšími dvěma nově registrovanými léky jsou antitrombotika, která se podávají perorálně, mají rychlý nástup účinku, účinek je konstantní, takže oba léky nevyžadují žádné laboratorní monitorování, podle kterého by se řídila denní dávka, jako je to nutné u warfarinu. Zatím jsou oba tyto léky registrovány pro prevenci hluboké žilní trombózy u velkých ortopedických operací. U obou léků ale probíhají klinické studie u nemocných s fibrilací síní, ve kterých jsou jejich účinky a bezpečnost srovnávány $\mathrm{s}$ warfarinem a slibují, že by se mohly v brzké budoucnosti stát pro nemocného př́ijemnější a také bezpečnější, i když zřejmě o hodně dražší alternativou $\mathrm{k}$ warfarinu.

Dabigatran (Pradaxa ${ }^{\circledR}$, Bohringer Ingleheim) je př́mým reverzibilním inhibitorem trombinu. Ve studiích, které porovnávaly jeho účinek $\mathrm{v}$ prevenci žilního tromboembolismu po ortopedických operacích, byl účinek srovnatelný s enoxaparinem včetně podobné bezpečnosti. Dabigatran se užívá perorálně jednou denně. Má poměrně rychlý nástup účinku (1-3 hodiny) a biologický poločas $12-17$ hodin. Je vylučován ledvinami a riziko lékových interakcí má nízké. V současné studii probíhá jeho klinické zkoušení i v dalších indikacích léčbě žilního tromboembolismu, akutních koronárních syndromů a v prevenci tromboembolických př́hod při fibrilaci síní.

Druhým antitrombotikem a prvním představitelem nové lékové skupiny př́mých reverzibilních inhibitorů aktivovaného hemokoagulačního faktoru X je rivaroxaban (Xarelto ${ }^{\circledR}$, Bayer). Podává se perorálně 1-2krát denně, jeho biologický poločas je 5-9 hodin. Z organismu se eliminuje jak renálním, tak hepatálním vylučováním a lékové interakce má minimální. Klinické studie prokázaly, že $\mathrm{v}$ prevenci tromboembolických př́hod u nemocných s operacemi velkých kloubů je účinnější než enoxaparin při stejném riziku krvácivých komplikací. Prevence tromboembolických príhod při velkých ortopedických operacích je také zatím jeho jediná schválená indikace. Podobně jako 
u dabigatranu, také s rivaroxabanem probíhají klinické studie u nemocných s akutními koronárními syndromy a nemocných s fibrilací síní.

Posledním ze čtveřice nově registrovaných léků je ranolazin (Ranexa ${ }^{\circledR}$, Menarini), lék s antianginózními a antiischemickými účinky, registrovaný pro profylaxi a léčbu anginy pectoris. Má zcela nový mechanismus účinku - inhibuje pozdní sodíkové kanály $\mathrm{v}$ myokardu komor. Blokáda těchto kanálů příznivě ovlivňuje metabolické nároky ischemického myokardu a snižuje jeho dráždivost. Ranolazin má relativně krátkou dobu účinku, proto se i v retardované formě podává perorálně dvakrát denně. Metabolizuje se na cytochromu CYP3A4, má proto vyšší riziko lékových interakcí - zejména riziko prodloužení intervalu QTc na EKG s rizikem komorových tachykardií typu torsades de pointes při současném podávání silných inhibitorů cytochromu CYP3A4 (např. verapamilu, amiodaronu, makrolidových antibiotik nebo azolových antimykotik). Vylučován je ledvinami.

A konečně v poslední části programového bloku HOTLINES přednesl jako aktualitu souhrnnou přednášku na téma „Nové obzory v antiarytmické léčbě fibrilace síní MUDr. Bytešník z Kliniky kardiologie IKEM. Představil v ní některá nová nadějná antiarytmika, jako již výše zmíněný dronedaron (viz studie ATHENA), vernakalant a další a nové strategie antiarytmické léčby. Tato přednáška byla jakousi protiváhou $\mathrm{k}$ mnoha sdělením o nemedikamentózní léčbě fibrilace síní katetrizační- mi ablačními technikami. Invazivní léčebné metody zažívají v elektrofyziologii mimořádný rozvoj a jsou nepochybně jedním $\mathrm{z}$ výkonných motorů současného bourllivého a oslnivého technologického pokroku v kardiologii. Vyvolávají však dojem, že vyřeší problém arytmií včetně té nejčastější - fibrilace síní - a že farmakologická antiarytmická léčba je odsouzena $\mathrm{k}$ brzkému zániku. Samozřejmě, že tomu tak není. V loňském roce byla např. katetrizační ablační léčba fibrilace/flutteru síní v České republice použita asi u 15000 nemocných. Představuje to přibližně $1 \%$ všech nemocných s fibrilací síní u nás.

Pracovní skupina Kardiovaskulární farmakoterapie také připravila hodinové postgraduální symposium na téma, které bývá na kardiologických kongresech poměrně opomíjené cévní mozkové př́hody (CMP). V symposiu nazvaném „Sekundární farmakologická prevence CMP“ zazněly čtyři přehledové přednášky. První uvedla posluchače do problematiky a seznámila je s epidemiologií a prognózou CMP u nás (MUDr. Bruthans) a $\mathrm{v}$ dalších byly postupně probrány tři lékové skupiny, které $\mathrm{v}$ současnosti tvoří páteř farmakologické prevence CMP - protidestičkové léky (prof. Hradec), blokátory receptorů $\mathrm{AT}_{1}$ pro angiotensin II (prof. Bultas) a hypolipidemika (MUDr. Vrablík).

Prof. MUDr. Jaromír Hradec, CSc.,

3. interní klinika, VFN a 1. LF UK, Praha

\section{Pracovní skupina Srdeční selhání}

Pracovní skupina Srdeční selhání se aktivně podílela na odborném programu a připravila několik zajímavých bloků přednášek.

Blok Jak můžeme zlepšit výběr pacientů pro resynchronizační terapii? byl velmi zajímavý, odpovídala tomu i hojná účast posluchačů. V první přednášce MUDr. Hegarová hovořila o úloze kardiologa při výběru nemocného pro resynchronizační léčbu. Prof. Meluzín se ve svém sdělení zaměřil na objasnění role echokardiografisty při indikaci resynchronizace. Ve své atraktivní přednášce upozornil na význam jednotlivých echokardiografických ukazatelů; v závěru ale uvedl, že žádný echokardiografický parametr není ideální pro předpověd’ účinnosti resynchronizace. MUDr. Čihák ve svém sdělení hodnotil postavení arytmologa, který provádí vlastní operační výkon, po němž se hodnotí a kontroluje stav resynchronizace.

Ve druhém dnu sjezdu následoval společný blok pracovní skupiny Srdeční selhání s pracovní skupinou Kardiovaskulární

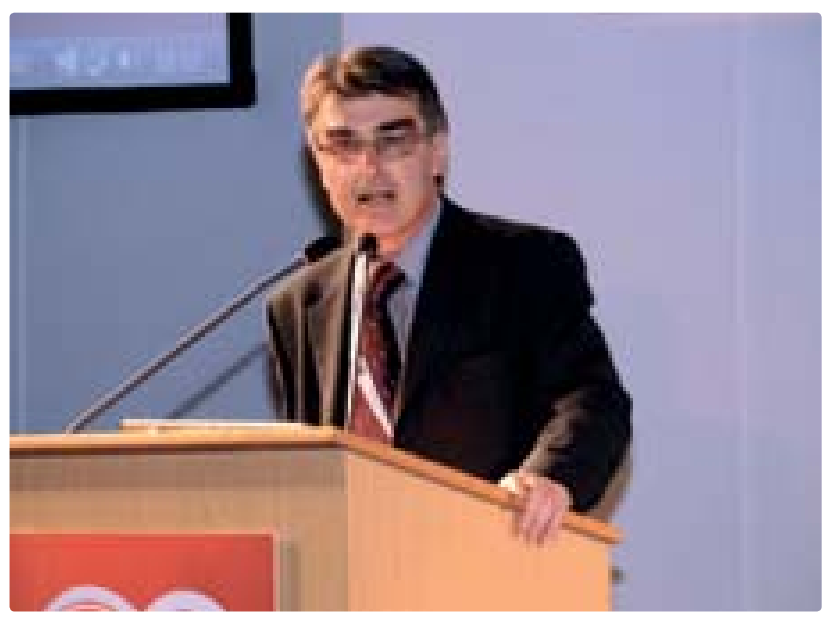

Doc. Václav Chaloupka (předseda České kardiologické společnosti) farmakoterapie na téma Kombinace inhibitorů ACE a sartanů $v$ léčbě srdečního selháni: Ano či Ne. Nejprve prof. Bultas uvedl problematiku blokády systému RAS v léčbě srdečního selhání v celé své komplexnosti. Prof. Vítovec hájil kombinaci inhibitorů ACE inhibitorů a sartanů, a to na základě dvou randomizovaných multicentrických studií Val-HeFT a CHARM Added, kdy se tato kombinace podílela zejména na zlepšení kvality života. Uvedl, že samozřejmě musíme pečlivě nemocné pro tuto kombinaci vybírat a kontrolovat jejich krevní tlak, renální funkce a hyperkalemii. Naopak, prof. Špinar uvedl argumenty proti používání této kombinace v léčbě chronického srdečního selhání. Upozornil na nebezpečí polypragmazie, nežádoucích účinků a zpochybnil údaje $z$ výše uvedených studií. Jeho plamenná př̀ednáška byla přesvědčivější, posluchači se nakonec v hlasování spíše klonili proti podávání kombinace inhibitorů ACE a sartanů. Na závěr oba předsedající - prof. Špinarová i prof. Hradec - uzavřeli souboj citací z evropských doporučení pro srdeční selhání, kde je tato kombinace uvedena jako možná alternativa léčby srdečního selhání.

Blok Neischemické srdeční selhání zcela zaplnil úterní odpoledne Rotundu pavilonu A. MUDr. Hošková uvedla novou klasifikaci kardiomyopatií; MUDr. Kubánek hovořil o diagnostice a léčbě myokarditid a zánětlivých kardiomyopatií; doc. Málek podal moderní přehled problematiky (včetně kasuistiky) pokročilých stadií hypertrofické a restriktivní kardiomyopatie.

Následoval blok Trénink u chronického srdečního selhání, kde nejdřive prof. Špinarová ukázala výhody dynamického tréninku u nemocných se srdečním selháním i u těžších případů. Hlavně část o alternativní dynamické zátěži v podobě tance, kterou nemocní absolvovali třikrát týdně, zaujala všechny přítomné. Prof. Špinarová, která patří mezi zakladatele této rehabilitace, spolu s prof. Tomanem prováděli ve spolupráci s Klinikou funkční diagnostiky FN u sv. Anny (prof. Siegelová, prof. Dobšák) výzkum v této oblasti. Přednáška doc. Chaloupky o bez- 


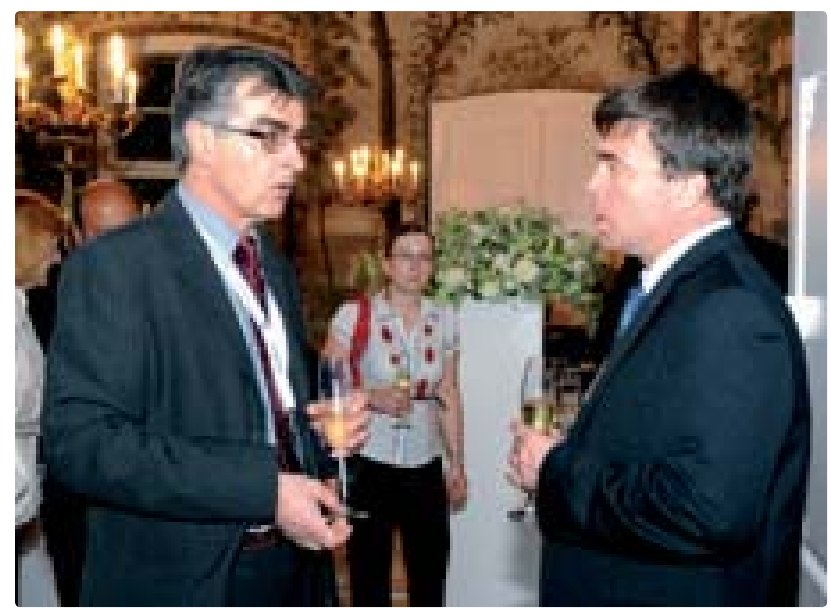

Mezi jednotlivými přednáškami probíhaly diskuse

pečnosti silového tréninku a jeho indikacích u nemocných s poruchou funkce levé komory ukázala, že i tato forma tělesného tréninku má své nezastupitelné místo. Doc. Chaloupka zdůraznil, že úlohou lékaře je určit přesnou dávku izometrického, ale i dynamického cvičení.

Poslední blok pracovní skupiny Srdeční selhání byl zaměřen na Význam tepové frekvence a dyslipidemie pro prognózu srdečního selhání a možnost jejich ovlivnění. Nejprve prof. Špinar vysvětlil význam tepové frekvence na prognózu srdečních onemocnění a zdůraznil, že tepová frekvence je hlavním př́íznakem zvýšené sympatické aktivity, která pak vede $\mathrm{k}$ rozvoji kardiovaskulárních onemocnění. Na mnoha metaanalýzách poukázal na to, že tepová frekvence $>70 /$ min podstatně zhoršuje prognózu nemocného. Prof. Vítovec uvedl možnosti léčby na snížení tepové frekvence. Na základě údajů provedl hodnocení beta-blokátorů, kdy přinášejí největší užitek nemocným (hlavně s ICHS a srdečním selháním). Blokátory vápníkového kanálu typu verapamil či diltiazem přinášejí v indikacích hypertenze či ICHS také příznivé údaje při respektování kontraindikací. Digoxin má své místo v léčbě srdečního selhání jako lék třetí volby, a to hlavně u fibrilace síní s rychlou odpovědí komor; ivabradin, blokátor $\mathrm{I}_{\mathrm{f}}$ kanálu v sinusovém uzlu neovlivňuje stažlivost.

Ve studii BEAUTIFUL ivabradin nevedl ke snížení mortality u nemocných se srdečním selháním ischemické etiologie. Došlo však ke snížení výskytu fatálních a nefatálních infarktů myokardu. Další studie SHIFT a SIGNIFY mají ukázat jeho účinnost bud'u srdečního selhání neischemické etiologie, a/nebo u nemocných s prokázanou ICHS, ale bez poruchy funkce levé komory. Ve druhé části prof. Špinarová ukázala prognostický význam dyslipidemie u srdečního selhání, kdy v mnoha studiích mají vyšší koncentrace cholesterolu u srdečního selhání pozitivní vliv. Prof. Hradec hovořil o možnostech a významu léčebných postupů u dyslipidemií; na studiích CORONA a GISSI HF ukázal, že léčba statiny u srdečního selhání nemá své opodstatnění; pouze $\mathrm{v}$ případě jasně prokázané ischemické etiologie u nemocných s vyšší plazmatickou koncentrací hs-CRP (nad $2 \mathrm{mg} / \mathrm{l}$ ) a nízkou hodnotou BNP či NT- proBNP jsou statiny u srdečního selhání indikovány.

Do bloku volných sdělení pracovní skupina doporučila dvanáct původních sdělení na téma srdeční selhání a srdeční transplantace.

Prof. MUDr. Jiří Vítovec, CSc.,

I. interní kardioangiologická klinika, FN u sv. Anny v Brně a LF MU, Brno

\section{Pracovní skupina Chlopenní a vrozené srdeční vady v dospělosti}

Sjezd byl po stránce organizační i odborné velmi dobře připraven a v tomto směru snese srovnání se sjezdem Evropské kardiologické společnosti. Zdařilý byl i galavečer ČKS, a to hlavně výběrem hudebních skupin, které přilákaly desítky účastníků na taneční parket a přispěly $\mathrm{k}$ dobré náladě všech zúčastněných. Nedílnou součástí byla i sportovní akce - Kardioběh Jiř́ho Tomana. Ne všichni však běhají nebo chtějí běhat, a proto by stálo za úvahu, zda paralelně $\mathrm{s}$ během nezorganizovat např. i cyklistický závod nebo závod na kolečkových bruslích. Možná, že by tyto aktivity přilákaly více účastníků sjezdu, a přispěly tak i $\mathrm{k}$ jeho ještě větší atraktivitě ...

Pracovní skupina Chlopenní a vrozené srdeční vady v dospělosti připravila čtyři bloky přednášek: Bikuspidální aortální chlopeň a její rizika - umíme je stratifikovat? (sál Morava, pondělí 11. 5., 8:30-10:30 hod.), Akutní disekce aorty (sál Morava, pondělí 11. 5., 10:30-12:30 hod.), Chlopenní a vrozené srdeční vady u žen a v těhotenství (sál Morava, úterý 12. 5 . 11:00-12:30 hod.) a Úskalí v diagnostice a léčbě mitrální insuficience (sál Morava, středa 13. 5., 8:30-9:30 hod.). Až na středeční symposium byl sál Morava přeplněn posluchači, takže někteří museli stát, což jistě nepřispívá ke komfortu při získávání nových informací. Při přípravě př́štího sjezdu tedy bude vhodné zamyslet se nad jiným rozvržením přednáškových sálů ...

Bikuspidální aortální chlopni se až donedávna nevěnovalo tolik pozornosti, kterou by si zasloužila. To byl zřejmě také důvod, proč symposium pracovní skupiny PS Chlopenní a vrozené srdeční vady v dospělosti přilákalo dav posluchačů. Pa- cienti s bikuspidální aortální chlopní tvoří velmi heterogenní populaci od vysoce rizikových nemocných s dilatací ascendentní aorty nebo s přítomnou aortální stenózou nebo regurgitací, až po málo rizikové nemocné s „normálně“ fungující bikuspidální chlopní bez dilatace ascendentní aorty. Dilatace ascendentní aorty má u nemocných s bikuspidální aortální chlopní progresivní charakter a pokračuje i po náhradě chlopně protézou; hlavním podkladem pro dilataci je změněná kvalita stěny aorty, pro mechanistickou představu prostého mechanického namáhání aortální stěny nemáme důkazy. Pacienti s bikuspidální aortální chlopní by měli být podle rizika echokardiograficky sledováni jednou až dvakrát ročně, pro autosomálně dominantní dědičnost by mělo být provedeno UZ vyšetření i u př́mých př́ibuzných.

Akutní disekce aorty je onemocnění s vysokou časnou mortalitou, proto rychlá a správná diagnostika je zcela zásadní pro další osud nemocného. Na symposiu byly $\mathrm{v}$ přehledu uvedeny výhody a nevýhody UZ, CT a MR vyšetření a současné možnosti chirurgické léčby disekcí aorty typu A. Komplikovaná disekce aorty typu B (ischemie orgánů při útlaku pravého lumen, hrozící ruptura aorty, progresivní dilatace aorty) je dnes v naprosté většině léčena endovaskulárně. S neustále se zlepšujícím instrumentáriem a s narůstajícími zkušenostmi intervenčních radiologů - kardiologů jsou dnes velmi přijatelné krátkodobé i střednědobé výsledky implantací stentgraftů.

Každý praktický kardiolog se ve své praxi čas od času setká $s$ těhotnou ženou, která má vrozenou srdeční vadu (VSV). Proto 
je důležité vědět, jaká rizika s sebou nesou jednotlivé VSV během těhotenství, při porodu a bezprostředně po něm. $V$ přednášce doc. Popelové (Praha) byly VSV rozděleny na vysoce a málo rizikové pro těhotenství a na VSV s těhotenstvím neslučitelné. Důraz byl kladen především na informování nositelek VSV o rizikách těhotenství a na "preventivni“ řešení vad (plastika/náhrada chlopně) ještě před těhotenstvím. MUDr. Koudelková (Praha) v přehledu uvedla specifika získaných chlopenních vad u žen.

Ischemická mitrální insuficience znamená pro pacienty nepříznivou prognózu a až dvakrát zvyšuje mortalitu nemocných. Proto jí bylo věnováno celé symposium. MUDr. Benešová (Praha) se zabývala problematikou správné diagnostiky a indikacemi k chirurgické léčbě, MUDr. Černý (Praha) v přehledu uvedl současné možnosti operačního řešení ischemické mitrální insuficience. Přestože jsou diagnostika a operační přístupy u této vady dobře propracované, zůstává řada otázek:

> Umíme předpovědět, komu pomůže izolovaná revaskularizace?

> Zlepšuje plastika zásadně přežití nemocných?

Zmírní řešení insuficience remodelaci levé komory?

> Co je optimální chirurgický př́stup?

Odpověd’ na tyto otázky zřejmě přinesou až další studie. Odpověd’ na první otázku může dát studie MUDr. Línkové (Praha), jejižz výsledky byly prezentovány v bloku volných sdělení „Chlopenní vady“. Autoři shrnují, že spolehlivé zlepšení u středně významné ischemické mitrální regurgitace po izolovaném CABG je pozorováno pouze u pacientů s viabilním myokardem a nepřítomnou dyssynchronií mezi papilárními svaly. Vliv na zmírnění stupně mitrální nedomykavosti má u „responderü“ i resynchronizační terapie - poster MUDr. Mráze (Praha). Dalším kontroverzním tématem na výše zmíněném symposiu byla „end-stage“ mitrální insuficience. Plastika mitrální chlopně může být racionálním postupem u pacientů s funkční mitrální nedomykavostí a symptomy srdečního selhávání jako součást komplexní péče o nemocné (medikamentózní léčba, resynchronizace ...) s př́ísně individuálním př́istupem.

Kromě symposií připravených PS Chlopenní a vrozené srdeční vady v dospělosti zaznělo na sjezdu (nebo bylo představeno formou posteru) přes 40 přednášek s problematikou srdečních vad. MUDr. Marek a spol. (Olomouc, Leicester) prezentovali první zkušenosti s implantací systému Mitrofast (prstenec a rigidní zadní cíp) při řešení prolapsu zadního cípu mitrální chlopně. MUDr. Štěrbáková (Plzeň) prezentovala výsledky studie zabývající se vztahem solubilních vaskulárních adhezivních molekul (sVCAM-1) a aortální stenózy. Zvýšená koncentrace sVCAM-1 je nezávisle spojena s kalcifikující aortální stenózou u pacientů s významnou koronární nemocí a zachovanou funkcí ledvin. Výsledky podporují hypotézu, že neoangiogeneze je důležitým patogenetickým mechanismem aortální stenózy. MUDr. Kovalová (Brno) studovala parametry mitrálního anulu u různých typů mitrální nedomykavosti a zjistila, že u Barlowovy choroby dochází s dilatací mitrálního anulu k významnému zvýšení sedlovitosti, u prolapsu mitrální chlopně anulus dilatuje, index sedlovitosti se zmenšuje.

MUDr. Miroslav Brtko, Ph.D., předseda pracovní skupiny Chlopenní a vrozené srdeční vady $v$ dospělosti

\section{Sesterská sekce}

Stejně jako loni měly o účast na XVII. sjezdu ČKS v Brně velký zájem zdravotní sestry. Zaregistrovalo se jich více než 1000. Odborný program volných sdělení byl rozdělen do pěti sekcí $\mathrm{v}$ průběhu tř́ dnů a dále dva přednáškové bloky byly připraveny výborem pracovní skupiny ošetřovatelství ČKS (PSOK).

Je nutno si připomenout, že ČKS je pokračovatelkou Československé kardiologické společnosti založené před 80 lety. Byla třetí na světě po USA a Německu. Letošního sjezdu se zúčastnil též současný př̀edseda výboru Evropské kardiologické společnosti (ESC) prof. Ferrari. Ve svém projevu se zabýval strukturou ESC a výhledem její činnosti na přístí léta. U této př́ležitosti upozornil také na významný podíl kardiologických sester v činnosti ve „stromu“ ESC, sdružených v Council on Cardiovascular Nursing and Allied Professions (CCNAP); organizace vznikla $\mathrm{v}$ roce 2006 transformací z původně pracovní skupiny č. 24 (založené v roce 1991); v současnosti sdružuje 24 pracovních skupin v rámci ESC. Od roku 2006 jsme také my součástí CCNAP.

$\mathrm{V}$ rámci sesterské sekce bylo předneseno 51 přednášek $\mathrm{z}$ různých oborů kardiologie a uvedeno osm posterů. Výbor PSOK připravil dva bloky se speciálně vybranými tématy a pozvanými přednášejícími.

Řada přednášek měla dobrou odbornou úroveň; zvýšil se podíl sdělení s popisem využití techniky při diagnostice a/nebo léčbě nemocných. Je vidět, že zavádění nových technologií do kardiologie má vzestupnou úroveň. Ukázalo se, že sestry se významně podílejí při obsluze náročné techniky; např. robotické navigace systému v diagnostice a léčbě arytmií; u pokročilých forem srdečního selhání s využitím extrakorporální membrá- nové oxygenace (ECMO) nebo intraaortální balonkové kontrapulsace (IABK), v nukleární kardiologii při diagnostice renovaskulární hypertenze aj., avšak při zachování pravidel ošetřovatelské péče o nemocné.

Sdělení zaměřená na ošetřovatelskou péči se týkala např. pacientů v kardiogenním šoku, po septální alkoholové ablaci pro hypertrofickou kardiomyopatii, pacientů s implantací ICD a biventrikulární stimulací, nemocných po transplantaci srdce, po radiálním přístupu v invazivní kardiologii atd. Přínosem byla také vystoupení zástupců záchranné služby zaměřené na kardiopulmonální resuscitaci (KPR). Ta byla doplněna $\mathrm{v}$ jiném sdělení, kde byly uvedeny výsledky průzkumu znalostí KPR u středně zdravotnických pracovníků. $\mathrm{V}$ rámci diskuse se jako nezbytná ukázala nutnost provádět nácvik KPR minimálně jednou za tři měsíce jak $\mathrm{v}$ ambulancích, tak i v nemocničních zař́zeních!

V posterové sekci byly práce dobře graficky i obsahově dokumentovány. $\mathrm{V}$ príśstím roce bude vhodné $\mathrm{k}$ nim zařadit diskusi v přestávce programu moderovaným způsobem.

Kasuistiky představují konkrétní pohled do „kuchyně“ ošetřovatelské péče. Z řady zajímavých prezentací lze uvést např. př́pad nemocné s Tako-tsubo kardiomyopatií, mladého pacienta s implantovaným ICD, nemocné s recidivující stenokardií po rekoronarografii a zajímavý osud mladé narkomanky s infekční endokarditidou, řešené kromě jiného i náhradou chlopní včetně náhledu na sociálně-ekonomické aspekty. Po dohodě s autorkami budou vybraná sdělení postupně publikována v „Rubrice kardiologických sester“ časopisu Cor et Vasa. 
Diskuse, významná součást přednášky, zůstává nadále slabinou programu. Jedním $\mathrm{z}$ úkolů předsedajících bude zahájit a navodit diskusi za účelem zisku dalších informací pro ostatní, kteří se danou problematikou nezabývají. Ke zvýšení společenské prestiže by prospěla účast lékařu při sdělení, aby poznali, jak dokáže spolupracující sestra prezentovat své pracoviště a podpořit tak její zájem o kardiologii.

Letošního sjezdu se též zúčastnila skupina kardiologických sester ze Slovenska, které se též zapojily do diskuse. Věřím, že $\mathrm{v}$ př́ístím roce se zúčastní ve větším počtu a také s vlastními sděleními z různých oborů kardiologie. Současně jim lze popřát úspěšné vykročení při založení pracovní skupiny Ošetřovatelství v kardiologii v rámci Slovenské kardiologické společnosti.

\section{A co letos príinesly bloky PSOK?}

Ošetřovatelství v kardiochirurgii přineslo řadu poznatků/znalostí z tohoto oboru nutných pro další dispenzární péči o nemocné. Př́nosné bylo úvodní sdělení o historickém vývoji kardiochirurgie od doby antické až po současnost. Dosahování dobrých výsledků, tj. velmi nízké perioperační a pooperační mortality v kardiochirurgii, úzce souvisí nejen s rozvojem a uplatněním technik při operaci - technika hluboké hypotermie, mimotělní membránová oxygenace (ECMO), ale i s uplatněním poznatků $\mathrm{v}$ ošetřovatelské péči. Vždyt průměrný věk operovaných nemocných, kteří jsou mnohdy polymorbidní, překračuje šesté decennium.

Za zajímavé lze považovat sdělení o průběhu zatím ojedinělého výkonu - o transplantaci srdce a plic u mladé nemocné a následné léčbě, ošetřovatelské péči a rehabilitaci v IKEM Praha. $\mathrm{V}$ programu bylo připraveno také originální sdělení s ukázkou péče o pacienta s plicní hypertenzí po endarterektomii plicnice.

Hlavní téma dalšího bloku PSOK bylo: „Současný stav primární a sekundární prevence kardiovaskulárních chorob v ČR a úloha sester $v$ její realizaci“. Toto téma by mělo patřit k nosným, celoplošným programům činnosti kardiologických sester, a to jak na pracovištích tak i ve společensky prospěšných aktivitách (ve spolupráci s pracovní skupinou Preventivní kardiologie a kardiovaskulární rehabilitace).

V další části programu seznámil předseda PSOK účastníky sjezdu s poznatky z IX. zasedání Spring Meeting CCNAP ESC, které uspořádala irská asociace kardiologických sester v Dublinu ve dnech 24.-25. 4. 2009. Dále hovořil o poslání edukační komise CCNAP ESC, kde máme zástupkyni v devítičlenné komisi (T. Pečánkovou, ÚVN Praha). Jsou vytvářeny předpoklady pro vytvoření jednotných edukačních standardů $\mathrm{v}$ kardiologii. V první řadě je cílem komise získat přehled o způsobu vzdělávání a kompetencích zdravotních sester ve státech Evropské unie a dalších zemích Evropy. Cílem bude vytvořit edukační plán vzdělávání. $\mathrm{Na}$ těchto aktivitách se bude podílet i naše PSOK.

Aktivity PSOK v roce 2008 a 2009 a výhled na rok 2010 byly obsahem další ćásti sdělení. V roce 2009 to byla II. jarní konference v Praze organizovaná Kardiologií s.r.o. na Bulovce.

Aktivní účastí se představil kolektiv kardiologie z Nemocnice Na Homolce na již výše zmíněné IX. konferenci CCNAP ESC, kde jsme poprvé měli i prezentaci ve formě posteru na téma: „Robotic therapy for atrial fibrillation ablation: Clinical Feasibility“. V př́pravné fázi jsou další akce: 18.-19. 9. 2009 ECHODNY ve Špindlerově Mlýně; 9. 10. 2009 III. odborná konference sester invazivní kardiologie (novinka) v Ostravě a 7. 11. 2009 III. edukačně-odborná konference v Praze. Ze zahraničních akcí se zástupci PSOK účastní 29. 8.-2. 9. 2009 kongresu ESC v Barceloně.

V závěrečné fázi prríprav je program „E-learning“ ve spolupráci se společností Sestra IN, který organizuje K. Malá (ÚVN Praha - katerina.mala@uvn.cz). Účast dalších kardiologických sester na tvorbě programů se očekává!

A jaké je výhled na rok 2010? Předpokládáme další rozvoj a prohlubování spolupráce s výborem ČKS (podpora sester při aktivitách v rámci CCNAP ESC apod.), s pracovními skupinami ČKS, s Českou asociací sester, pracovními skupinami sdružených v CCNAP ESC a výborem CCNAP ESC. Budeme podporovat zájem o členství kardiologických sester v ČKS a PSOK, podporovat aktivní účast na domácích i zahraničních akcích, zvyšovat podíl odborných př́spěvků, diskusí a jiných forem do Cor et Vasa, zvyšovat vzájemnou informovanost o aktivitách $\mathrm{v}$ regionech České republiky (cestou výboru PSOK), spolupodílet se na programu prevence kardiovaskulárních chorob.

V závěru je nutné připomenout, že podle stanov ČKS končí v listopadu 2009 období činnosti prvního výboru PSOK; ve dvou kolech se budou konat volby do výboru, budou probíhat písemně. Předpokládáme, že první kolo se uskuteční na počátku září 2009, kdy si všichni členové zvolí své zástupce. Nový výbor bude představen a zahájí svou činnost u př́ležitosti III. edukačně-odborné konference.

MUDr. Jiři Leso,

předseda pracovní skupiny Ošetřovatelství v kardiologii

\section{Kardiovaskulární rehabilitace}

Pracovní skupina Kardiovaskulární rehabilitace připravila pro letošní sjezd dva přednáškové bloky.

První blok pracovní skupiny byl v pondělí a tématem byla kardiovaskulární rehabilitace v současnosti. Úvodní přednášku pronesl MUDr. Karel (Praha) a seznámil publikum s neveselými fakty o úrovni kardiovaskulární rehabilitace v ČR. Spolu s MUDr. Skalickou (Praha) oslovili ta pracoviště, o kterých víme, že se tomuto typu rehabilitace věnují. Ačkoli bylo v roce 2006 registrováno v ČR zhruba 32000 pacientů s akutním koronárním syndromem a bylo provedeno asi 22500 koronárních angioplastik a 8000 kardiochirurgických výkonů, pouze malý zlomek pacientů dále rehabilituje (ve 2 . fázi asi $15-20 \%$, ve 3 . fáze asi 5-8 \% pacientů). Na 3. fázi rehabilitace se navíc podílí pouze malé množství pracovišt' (FN Brno, FN u sv. Anny, Brno, VFN

Praha, FN Olomouc, FN Motol Praha). Další přednáška byla věnována informačním zdrojům pro pacienty $\mathrm{v}$ kardiologii. Autorka doc. Sovová (Olomouc) poukázala na nedostatek validních materiálů pro pacienty a minimální počet pracovišt', která se zabývají cílenou edukací pacientů. MUDr. Skalická (Praha) pak ukázala, jak je složité, ba př́mo nemožné provádět kardiovaskulární rehabilitaci v ambulanci; důvodem je neexistence kódů zdravotních pojištoven a neexistující legislativa, která by umožnila kardiologovi tuto léčbu poskytovat. Blok vyzvaných přednášek zakončil doc. Chaloupka (Brno), který posluchače seznámil s výsledky studie kardiovaskulární rehabilitace u pacientů se srdečním selháním Action HF.

Další blok proběhl v úterý, jako volná sdělení z kardiorehabilitace, zaznělo zde celkem pět sdělení a všechna pochá- 
zela z pracoviště prof. Sieglové z FN u sv. Anny v Brně. Toto pracoviště je již dlouhodobě na čele výzkumu v kardiorehabilitaci; odpovídala tomu i vysoká úroveň všech přednášek. Škoda jen, že ostatní pracoviště se aktivně sjezdu nezúčastnila.

V průběhu sjezdu se také sešel nový výbor pracovní skupiny a MUDr. Karel předal předsednictví doc. Sovové. Výbor pak řešil hlavně nutnost vzniku kódu pro ambulantní rehabilitaci

\section{Kardioběh Jiř́ho Tomana}

V rámci XVII. výročního sjezdu České kardiologické společnosti se uskutečnil již 6. ročník Kardioběhu Jiř́ího Tomana. Běh se konal 12. 5. $2009 \mathrm{v}$ areálu BVV, sponzorován byl společností sanofi-aventis, zajištěn firmou Galant a měřil $3000 \mathrm{~m}$. Byl odstartován ráno v 6:45 známým sportovním komentátorem Štěpánem Škorpilem. Co bylo nesmírně potěšující, že se v ranním slunečném počasí na trat vydalo 109 běžců -78 mužů a 31 žen - mezi kterými tradičně nechyběli prof. Pirk, přednosta kardiochirurgie IKEM, prof. Aschermann, místopředseda ČKS, i prof. Vítovec, místopředseda organizačního výboru. Absolutním vítězem se stal již tradičně vítěz několika kardioběhů Petr Pospíšil z FN u sv. Anny v Brně v čase 8 min 57 s, druhým byl Petr Zajíček a třetím Jan Smolík. V kategorii žen letos ve vynikajícím čase 9 min 21 s zvítězila Klára Skoupá; v absolutním pořadí byla pátá, druhá byla Darina Krausová a třetí Veronika Plocová. Nejvíce obdivu zasloužil prof. Pirk, a možnosti vzniku akreditací pro provádění kardiovaskulární rehabilitace.

Úroveň sjezdu byla dobrá, musíme poděkovat organizátorům za jejich velké úsilí při zajištění plynulého konání akce.

Doc. MUDr. Eliška Sovová, Ph.D., MBA

přdsedkyně pracovní skupiny Kardiovaskulární rehabilitace

který dva dny před tímto během absolvoval pražský maraton a přesto se kardioběhu zúčastnil a doběhl ve skvělém čase 10 min $36 \mathrm{~s}$. Všichni aktivní běžci obdrželi drobné dárky od sponzora a první tři v kategorii žen a mužů byli odměněni na galavečeru ČKS krásnými soškami lékařek a lékařů se srdcem, které předávali paní Hana Tomanová, žena zesnulého prof. Tomana, na jehož památku se běh každoročně koná, dále prof. Michael Aschermann a Jiří Vítovec. Jak řekl na závěr předání cen prof. Aschermann: ... organizátoři př́štího 7. běhu (ale třeba jen kardiochůze) Jiř́ího Tomana věří, že účast bude opět hojná podle olympijského hesla: „Není důležité zvítězit, je důležité zúčastnit se“.

prof. MUDr. Jiř́ Vitovec, CSc., I. interní kardioangiologická klinika, FN u sv. Anny a LF MU, Brno

\footnotetext{
Seznam firem inzerujících v tomto čísle 